\title{
¿Cuáles son las implicancias de una reforma judicial con perspectiva de género?
}

(1) Débora D’Antonio

Diversos proyectos fueron enviados por el Poder Ejecutivo a poco de haber comenzado las sesiones parlamentarias ordinarias de 2020 con el propósito de llevar a cabo una serie de modificaciones en la estructura del sistema judicial. En teoría, los cambios propuestos estaban destinados a morigerar la persistencia de las enormes desigualdades existentes en "la administración de justicia". Estos prolegómenos provocaron oleadas de apoyo y de repudio masivas. Sin embargo, rápidamente quedaron expuestas las limitaciones a la hora de avanzar contra los presupuestos ideológicos centrales que estructuran el aparato judicial. Y las propuestas quedaron ceñidas a discusiones sobre la necesidad o no de unificar los fueros criminal y correccional, de duplicar la cantidad de juzgados y fiscalías, o de limitar el poder de los jueces federales con perfiles "altamente politizados". De modo que la cuestión de género que hubiese permitido poner patas para arriba las jerarquías sexuales del sistema permaneció en el debate tan solo como un elemento decorativo.

Quienes se han especializado en la relación entre género y Derecho han señalado que uno de los temas clave a postular en la agenda política es la enorme discordancia en el sistema judicial en materia de representación para las mujeres. Y, como en otros ámbitos de nuestra sociedad, resulta que hay una base mayoritariamente femenina, por ejemplo, en las unidades académicas donde se enseña "derecho" que colisiona con la exigua ocupación de puestos de decisión tanto a nivel nacional como provincial en los juzgados, en el fuero penal, en las distintas cámaras, en el Consejo de la Magistratura o en los cuerpos colegiados, entre otros. Algo por cierto relacionado con el tantas veces nombrado techo de cristal, que no opone normativa formal alguna, pero impide de facto los ascensos, al postular una desigual responsabilidad en torno a las tareas de gerenciamiento doméstico y de cuidado de menores y ancianos que condicionan la baja participación femenina, por ejemplo, en los concursos para obtener cargos de mayor responsabilidad y proyección y, por ende, con mejores salarios.

Se ha señalado, además, que la presencia de mujeres en espacios de decisión no garantiza en sí mismo la existencia de la perspectiva de género a la hora de aplicar la ley. No obstante, esta primera amplificación democrática resulta un requisito indispensable, aunque no sea suficiente. Es a partir de este peldaño, que resulta factible tramitar una serie de estrategias que permitan deconstruir las relaciones de poder en el sistema normativo y en las prácticas judiciales. También resulta clave una relectura del rol del sistema penal en tanto institución reproductora del sexismo jerárquico que desconoce derechos fundamentales de las mujeres, de las identidades feminizadas y de otras diversidades; así como incorporar la perspectiva de género a las investigaciones 
judiciales y no tan solo a los fallos y a las condenas. Como los actos legales forjan efectos que impactan de manera diferenciada en las subjetividades generizadas resulta de capital importancia diseñar políticas transversales que contemplen estos asuntos a la vez situados en marcos sociales, culturales y económicos específicos. ${ }^{1}$

Las contribuciones reunidas en esta sección "Debates" tienen por finalidad estimular la interrogación acerca de los límites y la trascendencia del género en el ámbito judicial. Los artículos trabajan con distintos ejes de análisis: calcanza una reforma en el Poder Judicial o debemos pensar la relación que se ha entablado entre el punitivismo, el feminismo y el mantenimiento de los dispositivos opresivos a nivel penal?, se pregunta Ileana Arduino anticipando ciertas vías de examen más complejas del problema. Marisa Tarantino, por su parte, nos interpela al establecer relaciones entre la institucionalización de los postulados neoabolicionistas como perspectiva mainstream para el abordaje judicial de los casos de trata de personas y el soslayamiento a la par de los derechos de las trabajadoras sexuales. Viviana Beigel propone la necesidad de una relectura global de la epistemología de los procesos judiciales, ya que las premisas en las que se asienta este campo se presentan como autoevidentes, eludiendo que están encuadradas en parámetros culturales que normalizan la discriminación por género. Por último, Juan Marco Vaggione cuestiona la categoría de género que se maneja para la reforma judicial en tanto esta prevee contemplar los derechos de las mujeres sin detenerse en el carácter plural de la misma y sin poner en tensión que toda juridificación de demandas políticas aplana o directamente instala un riesgo en los conflictos que provoca el accionar de los grupos antiderechos.

Se ha dicho que una reforma judicial en la Argentina es imprescindible, entre otras cosas, porque es el único poder no electivo que además no ha tramitado ningún proceso de revisión profundo. Estamos frente a una oportunidad histórica de hincarle el diente a esta estructura de poder vetusta, elitista, clasista y patriarcal y postular una organización judicial menos abyecta en su accionar. Valga este debate como referencia para una agenda de discusión absolutamente necesaria.

\footnotetext{
1 Ha habido distintos esfuerzos por parte del Ministerio Público Fiscal sobre Programas o Políticas de Género en el que cual, entre sus principales funciones, se ha propuesto: "asesorar a las fiscalías de los diferentes fueros y brindar la colaboración necesaria para la investigación y tratamiento de casos de desigualdad, discriminación o violencia de género en todas sus modalidades", así como "proyectar criterios generales de actuación que tiendan a optimizar la persecución penal y a disminuir la revictimización, en los casos de delitos que impliquen violencia de género". Ver Hacia una lgualdad de Género Compendio normativo, jurisprudencial y doctrinario, MPF, 2013. Disponible en: https://www. mpf.gob.ar/ufem/files/2014/o6/HIG-Programa_Politicas_Genero-versi\%C3\%B3n-
} 